DOI https://doi.org/10.30525/978-9934-26-074-2-39

\title{
МОБІНГ ТА ЙОГО АДМІНІСТРАТИВНО-ПРАВОВЕ РЕГУЛЮВАННЯ
}

\author{
Ткаля О. В. \\ кандидат юридичних наук, дочент, \\ доиент кафедри конституиійного \\ та адміністративного права і проиесу \\ Чорноморського національного університету імені Петра Могили \\ Климчук А.В. \\ студентка II курсу юридичного факультету \\ Чорноморського національного університету імені Петра Могили \\ м. Миколаїв, Україна
}

На даний момент тема мобінгу $є$ дуже актуальною, адже вона поширюється майже на кожного учасника робочого процесу. Судячи 3 численних закордонних публікацій, саме це підступне явище провокує звільнення з роботи, судові процеси, неврози, суїциди і матеріальні втрати, обчислювані в мільярдах. Незалежно від того, чи є ти кривдником або жертвою цього правопорушення, ти можеш стати свідком, тому важливо знати про відповідальність за цей проступок та шляхи захисту себе від порушення права на повагу до честі й гідності особи.

Вперше мобінг описав Хайнц Лейманн. За останні десятиліття мобінг є предметом досліджень А. Ваніорек, Л. Ваніорек, Р. Здибела, К. Клечека-Барана, Р. Поздзіка, А. Шалковські та ін. Цією проблемою в останні роки займались такі науковці як К. Ткачук, О. Смук, А. Сорокіна, I. Лопушинський, А. Маренич, О. Сердюк, О. Сорока, I. Філіпова та інші дослідники.

Мобінг (знущання, від англ. mob) - це систематичне цькування, терор, знущання, образливі слова та напади на якусь певну особу з метою iii звільнення або підриву авторитету. Насамперед це емоційне насильство. Зазвичай мобінг націлений на аутсайдерів у робочому колективі, яких систематично намагаються витіснити з ідеалізованого середовища. Це яскраво виражений колективний напад, який переростає в масштабний конфлікт. Під терміном мобінг розуміють вороже, неетичне ставлення однієї людини або групи людей, яке прямо спрямоване і систематично повторюється, головним чином, стосовно однієї особи, на якій дане переслідування відбивається негативно [1]. 
Міжнародна організація праці під психічним терором на робочому місці розуміє «образливе, мстиве, жорстоке, злостиве або принизливе поводження 3 окремою особою або групою працівників, що охоплює колективний пресинг (ganging up) або мобінг проти обраного працівника, який стає об'єктом психічного тиску. Мобінг передбачає постійну негативну увагу або критику, ізоляцію особи від суспільних контактів, поширення неправдивої інформації» [2]

Мобінг, як і булінг, та будь-який інший вид цькування людей, він має наслідки, які можуть набувати фатального характеру. Медичні дослідження, проведені в Свропі і США (там слово «мобінг» звучить сьогодні практично повсюдно), показали, що люди, які піддаються на роботі та в закладах освіти емоційному насильству, дуже швидко стають психологічно нестабільними [3, с. 262].

Мобінг як явище поділяється на типи, має свої передумови та наслідки. Його поділяють на два основні види - це вертикальний та горизонтальний. У випадку горизонтального - це переслідування та насильство, яке здійснюється співробітниками конкретного місця роботи в середині колективу. Горизонтальний - йде повністю з боку Керівництва, також такий вид булінгу ще називають босингом.

Мобінг виникає через низку різних причин, це може бути як особиста неприязнь, так і звичайне несприйняття. Також відбувається через те, що одному із працівників нудно і він хоче таким чином себе зацікавити. Одними із таких причин є: душевні хвороби, конкуренті причини, сексуалізація іншого працівника (із цього виходить мізотінія та харасмент), несприйняття в колективі і неадекватне ставлення (дискримінація іншого через колір шкіри, національність, мову і так далі). Наслідками даного проступку є створення неприємної атмосфери, зниження прибутку, відсутність мотивації, прогули, стрес, апатія, безсоння, появи суїцидальних думок та проблеми із алкогольними напоями і наркотичними речовинами, а також невдоволення населення і поширення мобінгу в Україні [4, с. 141].

Здебільшого у літературі мобінг визначають як психологічний терор, переважно груповий, який здійснюється щодо будь-якого учасника трудового процесу, який включає в себе систематичне приниження різного характеру. В Свропейському Союзі проблемі мобінгу приділяється значна частина уваги. У Франції, Швеції та Бельгії є ухваленими закони, що захищаються працівників від морального переслідування на роботі, а в Італії, Данії та Німеччині для цього $є$ прийнятим спеціальний закон «Про заборону дискримінації». Для прикладу, Франція регулює мобінг за допомогою спеціального нормативного акту, Закону «Про захист працівників від морального переслідування на роботі», 
а також нормами Трудового права, які передбачають санкції проти суб'єктів мобінгу.

В українському законодавстві поняття «мобінг» $€$ досить новим, адже не знаходить своє місце у правовій базі. У сучасному законодавстві пострадянських держав категорії «мобінг» і «булінг» відсутні, проте в Україні вже $\epsilon$ прийнятим Закон «Про цькування та штрафи за такі дії» від 18 грудня 2018 року, який стосується навчального процесу. Свого часу у Верховній Раді України було зареєстровано проєкт Закону «Про внесення змін до деяких законодавчих актів України щодо протидії мобінгу» №10118 від 01.03.2019, що дозволяло чекати в подальшій перспективі змін до Кодексу України про адміністративні правопорушення, а саме - главі 14, статті 173 , де раніше вже було додано доповнення стосовно булінгу учасника шкільного процесу. Але нажаль 29.08.2019 законопроект було відкликано.

Автори законопроекту планували визнати мобінг як правопорушення в трудовому колективі, що полягає в фізичному, психологічному та економічному насильстві. Вони планували даним законопроектом внести до Кодексу України про адміністративні правопорушення, а також до Закону України «Про колективні договори і угоди», в яких буде зазначено законодавчо поняття мобінгу і визначено відповідальність за систематичне застування різних форм цькування працівника [5].

Для кращого розуміння природи цього явища та правового регулювання відповідальності за дане правопорушення слід також враховувати, що мобінг може бути свідомий (навмисний) і несвідомий (стихійний). Свідомий - це цілеспрямовані дії, котрі мають конкретну, чітко сформульовану мету: створити людині такі умови, аби вона звільнилася із займаної посади. У такому випадку найчастіше йдеться про корисливі мотиви - обійняти чиюсь посаду, провести на неї когось зі «своїх», вислужитися перед начальством. Несвідомий - це коли людина не усвідомлює, що займається цькуванням, в наслідок особистої неприязні, постійного роздратування, що накопичується і вже просто проривається назовні.

Окрім цього важливо зазначати, що із прийняттям законопроекту про мобінг в Україні буде регламентована адміністративна відповідальність за мобінг у вигляді штрафу або громадських робіт. Розмір відповідальності доречно визначати відповідно до повторюваності винного діяння та суб'єкта. Повинно впливати те, чи вчинений даний проступок уперше, індивідуально чи групою осіб, спричинило психологічну або фізичну шкоду працівнику, а також - якщо це діяння вчиняється стосовно одинокої матері або батька. Також це правопорушення окрім юридичних заходів має керуватись спеціальними заходами, які будуть 
регулювати мобінг. Наприклад, одним із таких може бути превентивний захід, який буде обов'язковим для кожного, націлений на те, аби підтримувати дружню атмосферу в колективах. $\mathcal{C}$ потреба створення спеціальних стандартів, які б врівноважували будь-які недоліки в колективі, регулювали відносини. Мають бути проведені спеціальні бесіди та тренінги із всіма робітниками та керівництвом для того, аби навчити не боятись говорити та жалітись у випадку мобінгу. Для того, аби зменшити тенденцію цькування має бути адекватний правовий механізм, який буде не у вигляді карального тиску із боку правоохоронних органів, адже він навпаки стигматизує жертв як донощиків та виправдовує потребу в насильстві над ними замість захисту гідності та честі. Протидія мобінгу має концентруватись на тому, аби попередити, пояснити та уникнути, а не погіршити становище жертви [1].

Отже, мобінг - це один із видів булінгу, який виявляється у психологічному або фізичному, матеріальному пресингу з боку адміністрації або колег. Проблем мобінгу до кінця є недослідженою. На сьогоднішній день в Україні нема спеціально створеного механізму правового регулювання протидії цькування на робочому місці працівників, проте $\epsilon$ в розробці законопроєкт, який включає в собі пояснення терміну та перелік основних штрафів за такі дії. Мають бути вжиті спеціальні заходи для того, аби вдосконалити законодавство та атмосферу в робочу колективі. Для усунення даного деструктивного явища слід використовувати весь арсенал методів публічного адміністрування та запозичити кращий зарубіжний досвід.

\section{Лiтература:}

1. Ткачук К.Н., Гуменюк О.Л., Бивойно Т.П., Денисова Н.М. Челябієва В.М., Ткачук К.К., Буяльська Н.П. Безпека праці та промислова санітарія. Чернігів: ЧДТУ. 2010. 386 с. URL: http://ir.stu.cn.ua/ $123456789 / 19796$

2. Лагутіна I.B. Мобінг на робочому місці : правовий аспект. URL: http://www.apdp.in.ua/v57/18.pdf.

3. Смук О. Т., Мобінг як наслідок злоякісної агресії. Науковий вісник Ужггородського начіонального університету: серія: Педагогіка. Ужгород: Говерла. 2018. С. 260-264.

4. Сорокіна А. А., Мобінг та булінг в трудових відносинах. Науковий журнал «Молодий вчений». Херсон: Гельветика. 2018. С. 139-146.

5. Про внесення змін до деяких законодавчих актів України щодо протидії мобінгу (Проєкт Закону), № 10118 від 1.03.2019. URL: http://w1.c1.rada.gov.ua/pls/zweb2/webproc4_1?pf3511=65695 